\title{
Mental Healthy Movement Through Transcedental Meditation Program For Police Members At State Police School (Spn), Singaraja, Bali
}

\author{
Kartika Sari, Saktivi Harkitasari, Asih Primatanti \\ \{kartikadharma@gmail.com\} \\ Faculty of Medicine and Health Sciences, Warmadewa University
}

\begin{abstract}
Stress is a psychologically depressed condition caused by unpleasant physical or psychological experiences. Prolonged stress adversely affect the physical, intellectual, social, and spiritual conditions of the body, with the ability to threaten its physiological balance. Stress management is an effort to control and reduce tension that arises along with situations that are difficult to be overcome, therefore emotional and physical changes occur. One of the stress management efforts is Transcedental Meditation (TM) which was introduced by Maharishi Mahesh Yogi. In carrying out these community service activities, members of the police at the Singaraja State Police School (SPN), Bali and in collaboration with the Maharishi Global Raam Raj Foundation related to the initiation of the Transcedental Meditation program which is subsequently called "Mental Healthy Movement Through the Transcedental Meditation Program" are the main target. This activity is carried out at the State Police School, Buleleng, Bali. The results shows that the stress management program on police officers at the SPN reduces the stress experienced by participants. Therefore, it was concluded that the Transcendental meditation program reduces the stress levels possessed by police officers in accordance with the techniques and stages of training conducted by the Warmadewa University Service Team.
\end{abstract}

Keywords: Meditation, stress,

\section{Pendahuluan}

Stres adalah kondisi tertekan secara psikis yang disebabkan oleh pengalaman fisik maupun psikis yang tidak menyenangkan (Pramudanthi, 2016). Stres berkepanjangan dapat berdampak buruk bagi kondisi fisik, psikologis, intelektual, sosial, spiritual dan dapat mengancam keseimbangan fisiologis tubuh. Pada kondisi stres kronik, terjadi peningkatan produksi hormon stres yang tidak seimbang seperti kortisol, testosteron, epinefrin dan norepinefrin sehingga hal ini akan berakibat buruk bagi kesehatan (Maduka, 2015).

Beberapa hal yang dapat menjadi pemicu dari stress diantaranya kondisi fisik, psikososial dan lingkungan (Arisona, 2015). Lingkungan dan tuntutan kerja merupakan salah satu faktor utama penyebab stress, sebagai contoh adalah pekerjaan sebagai seorang polisi. Polisi adalah suatu perantara umum sipil yang mengatur tata tertib dan hukum. Fungsi kepolisian adalah salah satu fungsi pemerintahan negara di bidang pemeliharaan keamanan dan ketertiban 
masyarakat, penegakan hukum, perlindungan, pengayoman, dan pelayanan kepada masyarakat. Kepolisian Republik Indonesia juga mempunyai fungsi kamtibnas yaitu menjaga keamanan dan ketertiban masyarakat. Seperti halnya di sekolah pendidikan polisi di Sekolah Polisi Negara (SPN), angota kepolisian yang bertugas di SPN sangat rentan mengalami stress. Hal ini dikarenakan, petugas kepolisian yang memiliki peran ganda sebagai pendidik ini memiliki tanggung jawab untuk melahirkan polisi-polisi yang profesional, produktif, dan berkualitas. Oleh karena itu tentu banyak tuntutan yang diarahkan kepada anggota kepolisian RI yang bertugas di SPN. Menurut penelitian Khairudin pada tahun 2015, beberapa kondisi tersebutlah yang dapat memicu stres bagi anggota kepolisian sehingga mengakibatkan beberapa masalah kesehatan di kemudian hari salah satunya adalah Hipertensi. Maka dari itu, untuk meminimalisir dampak dari stres tersebut diperlukan adanya suatu upaya untuk manajemen stres. Manajemen stres adalah upaya untuk mengendalikan dan menurunkan ketegangan yang muncul bersama dengan situasi yang sulit diatasi sehingga terjadi perubahan emosional dan fisik (Mulyaningrum, 2010). Salah satu upaya manajemen stres adalah dengan Transcedental Meditation (TM). TM merupakan salah satu teknik meditasi yang diperkenalkan oleh Maharishi Mahesh Yogi. Dalam melakukan TM, seseorang harus rileks dengan posisi duduk dan mengucapkan mantram. Melalui teknik ini, pikiran secara alami akan tenang untuk mengalami tingkat yang lebih tenang dan lebih tenang yang disebut dengan yang disebut kesadaran Transendental (Nidich et al, 2015).

Penelitian terbaru menyebutkan bahwa teknik TM dapat mempengaruhi ekspresi gen telomer dan memberikan efek positif terhadap penurunan stres dan tekanan darah individu yang menderita hipertensi (Duraimani S, et al., 2015). Penurunan kondisi stres ini dikarenakan adanya gelombang otak alfa yang akan memicu pengeluaran hormon endorphin sehingga fisiologis tubuh kembali pada kondisi normal (Mendhurwar, S \& Gadkari, 2012).

Mengingat banyak sekali manfaat dari TM, kami merekomendasikan adanya inisasi program Transcedental Meditation ini sebagai salah satu kegiatan pendidikan di SPN yang akan bermanfaat dalam upaya manajemen stres dan meningkatkan vitalitas fisik anggota kepolisian. Dalam melaksanakan kegiatan pengabdian masyarakat ini, sasaran utama kami adalah anggota kepolisian di SPN Singaraja, Bali dan bekerjasama dengan Yayasan Maharishi Global Raam Raj terkait inisiasi program Transcedental Meditation yang selanjutnya kegiatan ini kami beri nama "Gerakan Sehat Mental Melalui Program Meditasi Transcedental". Kegiatan ini akan dilaksanakan di SPN Singaraja, Buleleng, Provinsi Bali

Adapun tujuan dilaksanakannya kegiatan ini adalah untuk meningkatkan pemahaman anggota kepolisian mengenai pentingnya menjaga kesehatan mental dan manajemen stress. Disisi lain, kegiatan ini juga diharapkan dapat meningkatkan pengetahuan dan kemampuan kader mengenai teknik menajemen stress yang baik untuk dilakukan sehari-hari serta metode yang digunakanuntuk mendeteksi kondisi kejiwaan secara dini

\section{Metode Pemecahan Masalah.}

Metode Pemecahan Masalah yang ditawarkan dalam kegiatan ini adalah sebagai berikut:

a. Melaksanakan dialog interaktif mengenai kesehatan mental dan pencegahan stress dengan melibatkan kader dan anggota Polri di SPN. Dari kegiatan ini diharapkan dapat meningkatkan pemahaman kader dan anggota Polri mengnai pentingnya manajemen stress yang baik.

b. Memberikan pelatihan bagi kader anggota Polri mengenai meditasi Transcendental di SPN. Program pengenalan dan latihan meditasi ini dilakukakn untuk memberikan 
pengalaman mengenai salah satu teknik menajemen stress yang baik untuk dilakukan sehari-hari. Pelatihan yang diberikan berupa pemberian materi mengenai meditasi Transcendental, teknik meditasi yang baik, sharing session, video session, serta simulasi.

c. Memberikan pengenalan tentang pentingnya mengenai kondisi kejiwaan atau mental sejak dini melalui tes DASS 42 (Depression, Anxiety and Stress Scales). Dari hasil tes ini, anggota akan mengenal sejak dini kondisi mental dan kejiwaan mereka serta meningkatkan pemahaman mengenai manajemen stress.

Adapun sasaran pada program ini adalah anggota kepolisian yang bertugas di SPN, Buleleng Bali. Anggota polisi tersebut memiliki tingkat stress yang tinggi dikarenakan latar belakang tugas di daerah rawan konflik dan saat ini bertugas sebagai pengajar di SPN.

\section{Hasil Kegiatan.}

Pelaksanaan Program "Gerakan Sehat Mental Melalui Program Meditasi Transcedental” dibagi menjadi 4 tahapan selama 6 kali pertemuan, yakni:

a. Tahap 1: Sosialisasi dan Perkenalan Meditasi Transcedental. Dalam tahap ini dilakukan penjelasan, pelaksanaan program penyuluhan dan pelatihan kader dilaksanakan pagi hari sebelum latihan fisik para anggota polisis di SPN Singaraja. Acara diawali dengan pembagian brosur kepada seluruh anggota polri di SPN Singaraja, dilanjutkan dengan pemberian pre-test. Setelah pemberian pre-test, kegiatan dilanjutkan dengan pemberian sosialisasi mengenai Transcendental Meditation berupa pemaparan dengan menggunakan power point atau sejenisnya. Kegiatan dilanjutkan dengan pembagian konsumsi dan diselingi dengan pemutaran video edukatif mengenai materi yang berkaitan dengan kegiatan sosialisasi yang telah disampaikan. Kegiatan ditutup dengan pemberian post-test, dimana pesertanya adalah anggota polisi yang mengikuti sosialisasi.

b. Tahap 2: Inisiasi Program

Tahap ini dilaksanakan pada pertemuan ke-2 yakni inisiasi program "Gerakan Sehat Mental Melalui Program Meditasi Transcedental" berupa pelatihan perorangan oleh trainer dari Yayasan Maharishi Global Raam Raj dengan waktu selama 2 jam, pada pelatihan ini diinformasikan mengenai metode dan syarat untuk melakukan Meditasi Transcen dental yang bertujuan untuk dapat mengurangi stres, kelelahan fisik dan mental dalam melaksanakan kegiatannya selama karantina di SPN Singaraja.

c. Tahap 3: Memverifikasi Hasil Program "Gerakan Sehat Mental Melalui Program Meditasi Transcedental" Tahap ini dilaksakan selama 5 hari untuk memverifikasi pengalaman dengan metode interview di hari ke-5 dan evaluasi tingkat stres diukur dengan menggunakan instrumen DASS 42.

d. Tahap 4: Follow Up dan Controlling Follow Up dan Controlling dilaksanakan setiap 1 bulan sekali selama 3 bulan. Evaluasi tingkat stres diukur dengan menggunkan instrumen DASS 42 dan pengukuran EEG. Berdasarkan hasil pengukuran diperoleh bahwa kemampuan manajemen stres yang dimiliki anggota polisi menjadi lebih baik. Terbukti dengan data yang diperoleh dari pengukuran tingkat stress yang menurun.

Pengukuran gelombang otak dengan EEG juga dilakukan untuk mengidentifikasi keberhasilan pelatihan meditasi kepada anggota polisi. Electroencephalogram adalah suatu instrumen yang digunakan untuk merekam aktivitas listrik statis yang dihasilkan dari rangsangan yang diterima otak. Electroencephalogram adalah perangkat yang dapat menangkap aktivitas listrik di otak dan menginformasikan kondisi pikiran seperti emosional, kelelahan, kewaspadaan, kesehatan dan tingkat konsentrasi (Li et al, 2008).

Sinyal EEG dibedakan berdasarkan rentang frekuensi dan diklasifikasikan menjadi lima gelombang, yaitu gelombang delta, theta, alpha, beta dan gamma. Hasil yang diperoleh adalah Gelombang alpha secara umum berkaitan dengan kondisi rileks dan kesadaran yang utuh. Dalam kondisi tanpa kecemasan, gelombang ini menunjukkan aktivitas yang tertinggi dan 
akan meningkat seiring dengan pengurangan kecemasan. Beberapa penelitian membandingkan aktivitas alpha pada meditators dan subjek kontrol. Hasil penelitian tersebut menghasilkan kesimpulan bahwa orang yang bermeditasi menunjukkan aktivitas alpha yang lebih tinggi dibandingkan kelompok kontrol.

\section{Kesimpulan}

Hasil kegiatan pengabdian masyarakat ini menunjukkan bahwa program manajemen stress pada anggota polisi di SPN Buleleng, Bali dapat menurunkan stres yang dialami oleh partisipan. Oleh karena itu, dapat disimpulkan bahwa program meditasi Transcendental ini dapat menurunkan tingkat stres yang dimiliki oleh anggota polisi sesuai dengan teknik dan tahapan pelatihan yang dilakukan oleh Tim Pengabdian Universitas Warmadewa.

\section{References}

[1] Arisona, A. A. (2015). Perbedaan Tingkat Stres Kerja Antara Anggota Polri Fungsi Reserse dengan Satlantas di Salatiga. Tesis, Fakultas Psikologi. Salatiga: Universitas Kristen Satya Wacana

[2] Duraimani S, Schneider RH, Randall OS, Nidich SI, XuS, Ketete M, et al. 2015. Effects of Lifestyle Modification on Telomerase Gene Expression in Hypertensive Patients: A Pilot Trial of Stress Reduction and Health Education Programs in African Americans. PLoS ONE 10(11): e0142689. doi:10.1371/journal.pone.0142689

[3] Li, L., Sun, L. M., \& Fan, X. Z. 2008. Probability distribution based time synchronization protocol for wireless sensor networks. Beijing Youdian Daxue Xuebao/Journal of Beijing University of Posts and Telecommunications, 31(5), 57-60.

[4] Maduka IC, Neboh E M, Ufelle SA. (2015) The Relationship between serum cortisol, adrenaline, blood glucose and lipid profile of undergraduate students under examination stress. African Health Sciences: 15 (1). 131-136.

[5] Mendhurwar, S., \& Gadkari, J. 2012. Effect of Transcendental meditation (TM) and Stress Management program on Respira-tory Rate and Breath holding Time-A comparative study. Journal of Clinical Research Letters, ISSN, 3(1), 19-23. Retrieved from https://scholar.google.nl/scholar?start=160\&q=\%22Transcendental+meditation $\% 22++$ stress\&hl= nl\&as_sdt $=0,5 \&$ as_ylo $=2011 \# 11$

[6] Nidich, S., Nidich, R. J., Salerno, J., Hadfield, B., Elder, C., Northwest, K. P. 2015. Nursing and Health Care Stress Reduction with the Transcendental Meditation Program in Caregivers : A Pilot Study. ClinMed.

[7] Pramudanthi, Hevalia. 2016. Efektivitas Meditasi Transendental untuk Menurunkan Stres pada Penderita Hipertensi. Skripsi, Fakultas Ilmu Pendidikan. Semarang: Universitas Negeri Semarang 